\title{
PENTINGNYA PERAN ORANG TUA DALAM PENGGUNAAN GADGET PADA ANAK USIA DINI
}

\author{
Nanang Sahriana \\ Program Studi PAUD Pascasarjana Universitas Negeri Semarang, Gedung A Kampus Pascasarjana J1 \\ Kelud Utara III, Semarang 50237, Indonesia
}

E-mail: nanang.sahriana@gmail.com, Telp: 082292674554

\begin{abstract}
Abstrak
Perkembangan teknologi saat ini sangatlah maju. Dengan demikian teknologi juga sangat mempengaruhi perkembangan anak usia dini. Saat ini siapa yang tidak mengenal gadget? Gadget merupakan perangkat elektronik kecil yang memiliki fungsi khusus. Banyak sekali fungsi, manfaat, dan dampak yang terjadi akibat gadget. Fungsi pengetahuan, media sosial, hiburan, game dan masih banyak lagi yang lainnya yang di dapat dari gadget. Perkembangan ini menghadirkan dampak baru bagi generasi muda khususnya bagi anak usia dini. Gadget sangat mudah sekali menarik perhatian dan minat anak dan sudah menjadi hal yang biasa jika anak-anak saja sudah memakai gadget dalam kehidupan sehari-hari. Gadget memiliki dampak positif dan negatif, untuk itu peran orang tua sangat penting dalam perkembangan teknologi yang sangat maju di zaman sekarang ini..
\end{abstract}

Kata kunci: Peran Orang Tua, Teknologi, Gadget, Anak Usia Dini.

\section{THE IMPORTANCE OF THE ROLE OF PARENTS IN THE USE OF THE GADGET AT EARLY CHILDHOOD}

\begin{abstract}
Current technological developments are very advanced. Thus technology also greatly affects the development of early childhood. Now, who doesn't know the gadget? The gadget is a small electronic device that has a special function. Lots of functions, benefits, and impacts that occur due to gadgets. The functions of knowledge, social media, entertainment, games and much more are obtained from the gadget. This development presents a new impact for the younger generation, especially for early childhood. The gadget is very easy to attract the attention and interest of children and it has become commonplace for children to use gadgets in their daily lives. Gadgets have a positive and negative impact, for that the role of parents is very important in the development of highly advanced technology in this day and age.
\end{abstract}

Keywords: The Role Of Parents, Technology, Gadget, Early Childhood

\section{PENDAHULUAN}

Saat ini kehidupan manusia tidak mungkin terlepas dari pengaruh globalisasi. Yang dapat dilakukan hanya bisa mengikuti derasnya arus globalisasi dan memanfaatkan dampak positif dari globalisasi. Salah satu pengaruh globalisasi yang sangat dirasakan yaitu perkembangan teknologi. Tidak dapat dipungkiri lagi bahwa sekarang teknologi telah berkembang kian pesatnya. Teknologi diciptakan untuk mempermudah urusan manusia. Berbagai macam jenis teknologi yang tidak terhitung jumlahnya dapat kita jumpai di zaman yang modern ini. Teknologi menjadi alat yang mampu membantu sebagian besar kebutuhan manusia. Teknologi telah dapat digunakan oleh manusia untuk mempermudah melakukan apapun tugas dan pekerjaan. Peran penting teknologi inilah yang membawa peradaban manusia memasuki era digital (Setiawan, 2017).

Perkembangan dunia teknologi saat ini makin pesat ke arah serba digital. Era digital telah membuat manusia memasuki gaya hidup baru yang tidak bisa dilepaskan dari perangkat yang serba elektronik. Teknologi menjadi alat yang membantu kebutuhan manusia. Dengan teknologi apapun dapat dilakukan dengan lebih 
mudah. Pada zaman yang semakin modern, perkembangan tehnologi di Indonesia kian hari kian bertambah. Terbukti dengan banyaknya pengguna gadget dengan berbagai merek dan tipe tersebar luas diseluruh wilayah Indonesia. Penggunanya tidak hanya orang dewasa saja akan tetapi anak usia dini pun ikut andil di dalamnya (Warisyah, 2015).

Disadari atau tidak kebiasaan lingkungan terhadap anak usia dini akan membentuk perkembangan anak. Pada saat ini seiring berkembangnya teknologi, banyak sekali yang berpengaruh pada anak salah satunya adalah penggunaan gadget. Gadget sangat mudah sekali menarik perhatian dan minat anak dan sudah menjadi hal yang biasa jika anak-anak saja sudah memakai gadget dalam kehidupan sehari-hari. Gadget memiliki dampak positif dan negatif. Untuk itu peran orang tua sangat penting dalam perkembangan teknologi yang sangat maju di zaman sekarang ini.

\section{PENGERTIAN GADGET}

Gadget adalah sebuah istilah dalam bahasa Inggris yang mengartikan sebuah alat elektronik kecil dengan berbagai macam fungsi khusus (Efendi, 2014). Dalam bahasa Indonesia, gadget disebut sebagai "gawai". Istilah gadget sebagai benda dengan karakteristik unik, memiliki sebuah unit dengan kinerja yang tinggi dan berhubungan dengan ukuran serta biaya (Rayner, 1956). Salah satu hal yang membedakan gadget dengan perangkat elektronik lainnya adalah unsur "kebaruan". Artinya, dari hari ke hari gadget selalu muncul dengan menyajikan teknologi terbaru yang membuat hidup manusia menjadi lebih praktis.

Setiap orang menggunakan gadget dengan teknologi yang modern seperti televisi, telepon genggam, laptop, komputer tablet, smartphone, dan lain-lain. Gadget ini dapat ditemui dimanapun, baik pada orang dewasa maupun anak-anak. Anak-anak kini telah menjadi konsumen aktif dimana banyak produk-produk elektronik dan gadget yang menjadikan anakanak sebagai target pasar mereka. Jangankan anak-anak, orang tua pun ada yang sangat menyukai gadget sampai disebut gadget freak.

\section{PERKEMBANGAN GADGET}

Panji Ismail (2013) mengatakan bahwa faktor semakin banyaknya teknologi yang bersaing menyebabkan harga dari gadget semakin terjangkau. Yang dulunya gadget adalah sesuatu yang sangat mahal, akan tetapi sekarang sudah tidak lagi. Dilihat dari kenyataan sekarang, sudah menjadi hal yang biasa bahwa anak-anak TK saja memiliki gadget berupa smartphone ataupun handphone sebagai bahan mainan mereka. Dahulu orang yang mampu membeli gadget hanyalah orang golongan menengah keatas, akan tetapi pada kenyataan sekarang orang tua berpenghasilan pas-pasan saja mampu membelikan gadget untuk anaknya.

Beberapa tahun yang lalu gadget hanya banyak di pakai oleh para pembisnis dari kalangan menangah ke atas. Alasan mereka menggunakan gadget adalah untuk memudahkan bisnis mereka. Namun pada zaman sekarang, gadget tidak hanya dipakai oleh para pembisnis saja, banyak para remaja bahkan anak-anak usia TK pun telah banyak menggunakan gadget. "Semakin banyak produk yang ada di pasaran, maka semakin tinggi pula tingkat konsumtif pelaku pasar." (Suhandi, 2013). Alasan para remaja dan anak-anak usia TK menggunakan gadget karena memiliki berbagi fungsi selain untuk berkomunikasi juga untuk berbagi, menghibur dengan audio, video, gambar, game, dan lain-lain. Bahkan dalam penelitian Sahriana (2018) mengatakan bahwa banyaknya anak-anak yang mengakses video di Youtube walaupun mereka belum mampu membaca tetapi mereka mengenali dari gambar atau simbol dari aplikasi tersebut. Hal ini menegaskan bahwa anak sudah sangat familiar dengan teknologi saat ini, apabila tidak ada pengawasan dari orang tua anak bisa saja mengakses video yang berisi konten-konten dewasa.

Semakin canggih zaman maka semakin banyak gadget yang akan digunakan tentunya apalagi sekarang ini semakin banyaknya aplikasi canggih yang berkembang dan terus berkembang pesat maka semakin banyak pula orang yang ingin memilih dan menggunakannya untuk kebutuhan dalam mencari dan mendapatkan informasi yang dibutuhkannya setiap harinya. Seperti yang diketahui, saat ini perkembangan gadget di Indonesia pertumbuhannya cukup pesat. Bahkan peminat gadget di Indonesia semakin bertambah dan hampir semua kalangan masyarakat gemar menggunakan gadget. Beberapa perusahaan gadget kini tengah berlomba-lomba untuk mengembangkan produk dengan keunggulan masing-masing. jadi bisa dipastikan beberapa tahun ke depan, teknologi gadget semakin trend. 
Sekarang tidak hanya kalangan atas saja yang dapat memiliki tablet dan smartphone. Namun kalangan menengah juga sudah dapat memiliki sebuah tablet dan smartphone karena semakin bersaing nya di pasaran untuk membuat harga gadget semakin ekonomis. Karena itu banyak produk-produk baru yang menawarkan gadget dengan harga yang cukup murah. Karena itu lah sekarang orang dengan mudah untuk memiliki sebuah gadget. Tak heran juga permainan yang dimainkan anak zaman sekarang berbeda dengan dulunya.

\section{PENGARUH GADGET TERHADAP PERKEMBANGAN ANAK}

Berbagai penelitian dari kedokteran maupun dunia psikolog mengenai dampak gadget telah dilakukan. Gadget memiliki pengaruh besar terhadap kehidupan manusia, demikian pula terhadap anak-anak usia dini. Dari segi psikologis, masa kanak-kanak adalah masa keemasan (golden age) dimana anak-anak belajar mengetahui apa yang belum diketahuinya. Jika masa kanak-kanak sudah tercandu dan terkena dampak negatif oleh gadget, maka perkembangan anakpun akan terhambat khususnya pada segi prestasi.

Satu hal yang sering dilupakan adalah efek negatif dari radiasi gadget dapat mempengaruhi kesehatan tubuh manusia, terutama bagi anak-anak. Alasan mengapa kebanyakan orang, terutama anak-anak, mengabaikan fakta ini karena kurangnya pengawasan dari orang tua atau pengasuh mereka (Vincent Jonathan S., DR. Prayanto W.H., M.Sn., Hen Dian Yudani, S.T., 2011).

Beberapa faktor yang membuat gadget sangat berpengaruh antara lain adalah:

a. Gadget semakin hari semakin canggih

Hal ini tentu memberikan banyak manfaat yang mempermudah pekerjaan. Apalagi dengan ukurannya yang terbilang kecil, gadget mudah dibawa kapan pun dan dimana pun. hal inilah yang membuat gadget seolah-olah menjadi sebuah barang yang tidak bisa terpisahkan dari aktivitas manusia. Selain itu gadget dilengkapi juga dengan fitur game yang sangat menarik minat anak-anak.

b. Secara tidak sadar gadget membuat ketergantungan.

"Secara tidak sadar, saat ini anak-anak sudah mengalami ketergantungan menggunakan gadget. Ketergantungan inilah yang menjadi salah satu dampak negatif yang sangat berpengaruh.” (Eko prasetyo, 2013) Contohnya saja handphone. Sehari saja tidak mnggunakan handphone pasti ada rasa yang mengganjal.

\section{DAMPAK POSITIF DAN NEGATIF DARI PENGARUH GADGET PADA ANAK}

Bak pisau yang memiliki dua sisi, keberadaan gadget membawa kebaikan sekaligus dampak negatif terutama pada anak. Dokter anak asal Amerika Serikat Cris Rowan menegaskan, harus ada pelarangan penggunaan gadget pada anak berusia di bawah 12 tahun. Sebab, tidak sedikit penelitian yang membuktikan, gadget lebih banyak membawa dampak negatif ketimbang manfaat bagi anak. Dampak pengaruh gadget pada perkembanan anak sangat banyak. Dampak yang diberikan dari segi pendidikan di Indonesia terbagi dua yaitu, dampak positif dan dampak negatif.

Dampak positif

a. Menambah Pengetahuan

Rizki Syaputra, Dhani. (2013) menyimpulkan bahwa dengan menggunakan gadget yang berteknologi canggih, anak-anak dengan mudah dan cepat untuk mendapatkan informasi mengenai tugas nya disekolah. Misalnya kita ingin browsing internet dimana saja dan kapan saja yang ingin kita ketahui. Dengan demikian dari internet kita bisa menambah ilmu pengetahuan.

b. Memperluas Jaringan Persahabatan

Gadget dapat memperluas jaringan persahabatan karena dapat dengan mudah dan cepat bergabung ke sosial media. Jadi, kita dapat dengan mudah untuk berbagi bersama teman kita.

c. Mempermudah Komunikasi

Gadget merupakan salah satu alat yang memiliki tekonologi yang canggih. Jadi semua orang dapat dengan mudah berkomunikasi dengan orang lain dari seluruh penjuru dunia.

d. Melatih kreativitas anak

Kemajuan teknologi telah menciptakan beragam permainan yang kreatif dan menantang. Banyak anak yang termasuk kategori ADHD diuntungkan oleh permainan ini oleh karena tingkat kreativitas dan tantangan yang tinggi. Menurut Baihaqi dan Sugiarmin (2006: 2) ADHD sendiri merupakan singkatan dari Attention Deficit Hyperactivity Disorder yang merupakan gangguan perkembangan dalam peningkatan aktivitas motorik anak-anak hingga 
menyebabkan aktivitas anak-anak yang tidak lazim dan cenderung berlebihan.

Dampak negatif

a. Mengganggu Kesehatan

Gadget dapat mengaganggu kesehatan manusia karena efek radiasi dari teknologi sangat berbahaya bagi kesehatan manusia terutama pada anak-anak yang berusia 12 tahun kebawah. Efek radiasi yang berlebihan dapat mengakibatkan penyakit kanker.

b. Dapat Mengganggu Perkembangan Anak

Gadget memilki fiture-fiture yang canggih seperti, kamera, video, games dan lainlain. Fitur itu semua dapat mengganggu proses pembelajaran di sekolah. Misalnya ketika guru menerangkan pelajaran di depan salah satu siswa bermain gadget nya di belakang atau bisa juga di pergunakan sebagai alat untuk hal-hal yang tidak baik.

c. Rawan terhadap tindak kejahatan

Setiap orang pasti ada yang memiliki sifat update di mana saja. Jadi orang ingin berbuat kejahatan dengan mudah mencari nya dari hasil update nya yang boleh dibilang terlalu sering.

d. Dapat Mempengaruhi perilaku Anak

Kemajuan teknologi berpotensi membuat anak cepat puas dengan pengetahuan yang diperolehnya sehingga menganggap apa yang didapatnya dari internet atau teknologi lain adalah pengetahuan yang terlengkap dan final" (Ratih Ibrahim, 2012). Pada faktanya ada begitu banyak hal yang harus digali lewat proses pembelajaran tradisional dan internet tidak bisa menggantikan kedalaman suatu pengetahuan. Kalau tidak dicermati, maka akan ada kecenderungan bagi generasi mendatang untuk menjadi generasi yang cepat puas dan cenderung berpikir dangkal.

Kemajuan teknologi yang membawa banyak kemudahan, generasi mendatang berpotensi untuk menjadi generasi yang tidak tahan dengan kesulitan. Dengan kata lain, anak akan berpikir atau merasa bahwa hidup ini seharusnya mudah dan pada akhirnya anak berusaha untuk menyederhanakan masalah dan berupaya menghindari kesukaran.

Kemajuan teknologi mempercepat segalanya dan tanpa disadari anak pun dikondisikan untuk tidak tahan dengan keterlambatan. Hasilnya anak makin hari makin lemah dalam hal kesabaran serta konsentrasi dan cepat menuntut orang untuk memberi yang diinginkannya dengan segera.
Romo (2013) mengatakan bahwa bermain gadget dalam durasi yang panjang dan dilakukan setiap hari secara kontinyu, bisa membuat anak berkembang ke arah pribadi yang antisosial. Ini terjadi karena anak-anak ini tidak diperkenalkan untuk bersosialisasi dengan orang lain. Selain itu juga berpotensi mendorong anak untuk menjalin relasi secara dangkal. Waktu untuk bercengkerama secara langsung berkurang karena sekarang waktu tersita untuk menikmati semuanya dalam kesendirian.

\section{PERAN ORANG TUA DALAM MENGATASI DAMPAK NEGATIF DARI GADGET}

Sosok yang paling berpengaruh dalam mencegah maupun mengatasi dampak negatif dari gadget adalah orang tua. Maka orang tua memiliki peran besar dalam membimbing dan mencegah agar teknologi gadget tidak berdampak negatif bagi anak. Jovita Maria Ferliana (2013) menjelaskan cara-cara yang harus dilakukan oleh orang tua ialah sebagai berikut :

1. Pilih sesuai usia

Dilihat dari tahapan perkembangan dan usia anak, pengenalan dan penggunaan gadget bisa dibagi ke beberapa tahap usia. Untuk anak usia di bawah 5 tahun, Pemberian gadget sebaiknya hanya seputar pengenalan warna, bentuk, dan suara. Artinya, jangan terlalu banyak memberikan kesempatan bermain gadget pada anak di bawah 5 tahun. Terlebih di usia ini, yang utama bukan gadget-nya, tapi fungsi atau peran orangtua. Pasalnya gadget hanya sebagai salah satu sarana untuk mengedukasi anak.

Ditinjau dari sisi neurofisiologis, otak anak berusia di bawah 5 tahun masih dalam taraf perkembangan. Perkembangan otak anak akan lebih optimal jika anak diberi rangsangan sensorik secara langsung. Misalnya, meraba benda, mendengar suara, berinteraksi dengan orang, dan sebagainya. Jika anak usia di bawah 5 tahun menggunakan gadget secara berkelanjutan, apalagi tidak didampingi orangtua, akibatnya anak hanya fokus pada gadget dan kurang berinteraksi dengan dunia luar.

Yang berikutnya, otak bagian depan adalah bagian yang berfungsi memberi perintah dan menggerakkan anggota tubuh lainnya. Di bagian otak belakang, ada yang namanya penggerak. Di bagian ini, terdapat hormon 
endorfin yang mengatur pusat kesenangan dan kenyamanan. Pada saat bermain gadget, anak akan merasakan kesenangan, sehingga memicu meningkatnya hormon endorfin. Kecanduan berhubungan dengan ini jika dilakukan dalam jangka waktu lama dan kontinyu. Akibatnya, ke depannya, anak akan mencari kesenangan dengan jalan bermain gadget, karena memang sudah terpola sejak awal perkembangannya.

Dari aspek interaksi sosial, perkembangan anak-anak usia di bawah 5 tahun sebaiknya memang lebih ke arah sensor-motorik. yaitu, anak harus bebas bergerak, berlari, meraih sesuatu, merasakan kasar-halus. Memang di gadget juga ada pengenalan warna atau games di mana orang melompat. Namun, kemampuan anak untuk berinteraksi secara langsung dengan objek nyata di dunia luar tidak diperoleh anak.

2. Batasi waktu

Anak usia di bawah 5 tahun, boleh-boleh saja diberi gadget. Tapi harus diperhatikan durasi pemakaiannya. Misalnya, boleh bermain tapi hanya setengah jam dan hanya pada saat senggang. Contohnya, kenalkan gadget seminggu sekali, misalnya hari Sabtu atau Minggu. Lewat dari itu, ia harus tetap berinteraksi dengan orang lain. Aplikasi yang boleh dibuka pun sebaiknya aplikasi yang lebih ke fitur pengenalan warna, bentuk, dan suara.

Sejalan pertambahan usia, ketika anak masuk usia pra remaja, orangtua bisa memberi kebebasan yang lebih, karena anak usia ini juga perlu gadget untuk fungsi jaringan sosial mereka. Di atas usia 5 tahun (mulai 6 tahun sampai usia 10 tahun) orangtua bisa memperbanyak waktu anak bergaul dengan gadget. Di usia ini, anak sudah harus menggali informasi dari lingkungan. Jadi, kalau tadinya cuma seminggu sekali selama setengah jam dengan supervisi dari orangtua, kini setiap Sabtu dan Minggu selama dua jam. Boleh main games atau browsing mencari informasi. Intinya, kalau orang tua sudah menerapkan kedisiplinan sedari awal, maka di usia pra remaja, anak akan bisa menggunakan gadget secara bertanggungjawab dan tidak kecanduan gadget.

3. Hindarkan kecanduan

Kasus kecanduan atau penyalahgunaan gadget biasanya terjadi karena orangtua tidak mengontrol penggunaannya saat anak masih kecil. Maka sampai remaja pun ia akan melakukan cara pembelajaran yang sama. Akan susah mengubah karena kebiasaan ini sudah terbentuk. Ini sebabnya, orang tua harus ketat menerapkan aturan ke anak, tanpa harus bersikap otoriter. Dan jangan lupa, orangtua harus menerapkan reward and punishment. Kalau ini berhasil dijalankan, maka anak akan bisa melakukannya secara bertanggungjawab dan terhindar dari kecanduan.

Ciri-ciri anak yang sudah kecanduan antara lain: (a) anak menghabiskan sebagian besar atau seluruh waktunya hanya untuk bermain dengan gadget. (b) anak mengabaikan/mengesampingkan kebutuhan lain hanya untuk bermian gadget. Misalnya lupa makan, lupa mandi. (c) anak mengabaikan teguran-teguran dari orang sekitar

4. Beradaptasi dengan zaman

Salah satu dampak positif gadget adalah akan membantu perkembangan fungsi adaptif seorang anak. Artinya kemampuan seseorang untuk bisa menyesuaikan diri dengan keadaan lingkungan sekitar dan perkembangan zaman. Jika perkembangan zaman sekarang muncul gadget, maka anak pun harus tahu cara menggunakannya. Artinya fungsi adaptif anak berkembang. seorang anak harus tahu fungsi gadget dan harus bisa menggunakannya karena salah satu fungsi adaptif manusia zaman sekarang adalah harus mampu mengikuti perkembangan teknologi. Sebaliknya, anak yang tidak bisa mengikuti perkembangan teknologi bisa dikatakan fungsi adaptifnya tidak berkembang secara normal. Namun, fungsi adaptif juga harus menyesuaikan dengan budaya dan tempat seseorang tinggal. Kalau anak tinggal di sebuah desa dimana gadget adalah barang langka, maka wajar kalau anak tidak tahu dan tidak kenal yang namanya gadget.

\section{PENUTUP}

Secara tidak sadar, saat ini manusia sudah mengalami ketergantungan menggunakan gadget. Ketergantungan inilah yang menjadi salah satu dampak negatif kehadiran gadget. Contohnya saja handphone. Sehari saja tidak mnggunakan handphone pasti ada rasa yang mengganjal.

Orang tua harus tegas atau tidak boleh memanjakan anaknya yang umurnya dibawah 12 tahun untuk menggunakan gadget. Karena lebih banyak dampak negatif yang timbul apabila seorang anak di bawah umur telah diberikan gadget. Salah satu dampak negatif yang terjadi ialah dapat membuat anak menjadi malas, mengganggu kesehatannya dan juga dapat menyalah gunakan fungsi gadget. 
Maka sebaiknya orang tua perlu memikirkan apa yang boleh diberikan oleh anak-anaknya yang masih berumur dibawah 12 tahun. Apabila ingin memberikan nya juga haruslah selalu tetap mengontrol penggunaan gadget nya jangan terlalu berikan kebebasan yang berlebihan. Dan juga melarangnya untuk membawa gadget ke sekolah, karena bisa menghambat proses pembelajarannya di sekolah.

Teknologi jelas mempengaruhi perkembangan anak karena sebuah perangkat teknologi merupakan media pembelajaran yang sangat efektif. Dengan adanya tampilan gambar yang bias berjalan, efek suara atau nyanyian membuat media pembelajaran dengan memanfaatkan perangkat teknologi sangat disukai oleh anak-anak. Dan karena kemajuan teknologi juga dapat membantu daya kreativitas anak, jika pemanfaatnya diimbangi dengan interaksi dengan lingkungan sekitarnya. Dengan terlalu membebaskan anak dibawah umur menggunakan teknologi yang terlalu canggih seperti gadget maka itu dapat mengubah perilaku seorang anak, untuk itu peran orang tua sangat penting.

Orang tua harus tegas atau tidak boleh memanjakan anaknya yang umurnya dibawah 6 tahun untuk menggunakan gadget. Karena lebih banyak dampak negatif yang timbul apabila seorang anak di bawah umur telah diberikan gadget. Salah satu dampak negatif yang terjadi ialah dapat membuat anak menjadi malas, mengganggu kesehatannya dan juga dapat menyalah gunakan fungsi gadget.

Maka sebaiknya orang tua perlu memikirkan apa yang boleh diberikan oleh anak-anaknya yang masih berumur dibawah 6 tahun. Apabila ingin memberikan nya juga haruslah selalu tetap mengontrol penggunaan gadget nya jangan terlalu berikan kebebasan yang berlebihan. Dan juga melarangnya untuk membawa gadget ke sekolah, karena bisa menghambat proses pembelajarannya di sekolah.

Orang tua harus berani mengubah dirinya sendiri, jika selama ini ada yang salah. Jika selama ini egois, selama ini mau menang sendiri terhadap anak, otoriter, itu harus berani diubah untuk kepentingan bersama. Jadi, ada saatnya orang tua menjadikan anak sebagai satu titik fokus terpenting untuk perkembangan dan masa depan anak itu sendiri. Sehingga masa pertumbuhan dan perkembangan anak lebih terarah dan menghasilkan psikologi anak yang baik pula. Seperti kata pepatah "buah jatuh tak pernah jauh dari pohonnya" anak yang tumbuh kembang yang baik berasal dari didikan dan pengawasan yang baik dari orangtuanya.

\section{DAFTAR PUSTAKA}

Cvano, Osland. 2013. Pengertian_Gadget. [Online]. Tersedia: http://mencobacariduit.blogpot.com/201 3/09/pengertian-gadget.html / 2013/ [17 Oktober 2018]

Efendi, M. F. 2014. Pengaruh Gadget terhadap Anak Usia Dini. [Online]. Tersedia: http://fuadefendi.blogspot.in/2014/01/pe ngaruh-gadgetterhadapperkembangan.html.

Hartati, Sofia. 2007. How to be a Good Teacher and to be a Good Mother. Jakarta: Enno Media.

Hastuti. 2012. Psikolog Perkembangan Anak. Yogyakarta: Tugu Publisher.

Novariaa, I dan Triton P.B. 2008. Cara pintar mendampingi anak. Yogyakarta: Tugu Publisher.

Metta. 2015. Kapan waktu tepat memeperkenalkan gadget pada anak. [Online]. Tersedia: http://bidanku.com/kapan-waktu-tepatmemperkenalkan-gadget-pada-anak. [17 Oktober 2018]

Prasetyo, Eko. 2017.Gadget. [Online]. Tersdia: http://epzna.blogspot.com/2013/08/gadg et.html [17 Oktober 2018]

Sahriana, Nanang \& Yuli Kurniawati Sugiyo Pranoto. 2018. Perception of Preschoolers (3-7 years) on Usage of YouTube in Semarang. Prociding 4th International Conference on Early Childhood Education. Semarang Early Childhood Research and Education Talks (SECRET), 27-33.

Setiawan, W. 2017. Era Digital dan Tantangannya. Seminar Nasional Pendidikan 2017, 1-9.

Sujiono, Yuliani Nurani. 2009. Konsep Dasar Pendidikan Anak Usia Dini. Jakarta: PT Indeks.

Miftah Normalitta. 2018. Ini Pentingnya Peran Orang Tua dalam Penggunaan Gadget 
Bagi Anak-Anak. [Online]. Tersedia: https://www.hipwee.com/opini/inipentingnya-peran-orang-tua-dalampenggunaan-gadget-bagi-anak-anak/ [2 Januari 2019].

Vincent Jonathan S., Prayanto W.H.,., Hen Dian Yudani. 2011. Gadget Terhadap Anak Pendahuluan. Perancangan Board Game Mengenai Bahaya Radiasi Gadget Terhadap Anak, 1-15.

Warisyah, Y. 2015. Pentingnya "Pendampingan Dialogis" Orang Tua Dalam Penggunaan Gadget Pada Anak Usia Dini. Prosiding Seminar Nasional Pendidikan "Inovasi Pembelajaran Untuk Pendidikan Berkemajuan, 130138. 